\title{
GAMBARAN KARIES DAN KEBUTUHAN PERAWATAN \\ RESTORASI PADA MASYARAKAT DI KELURAHAN \\ PAPUSUNGAN KECAMATAN LEMBEH SELATAN
}

\author{
${ }^{1}$ Renny Diane Cheryl Putong \\ ${ }^{2}$ Vonny N. S. Wowor \\ ${ }^{3}$ Dinar A. Wicaksono
}
${ }^{1}$ Kandidat skripsi Program Studi Kedokteran Gigi Fakultas Kedokteran Universitas Sam Ratulangi
${ }^{2}$ Bagian Ilmu Kesehatan Gigi Masyarakat Program Studi Kedokteran Gigi Fakultas Kedokteran Universitas Sam Ratulangi
${ }^{3}$ Bagian Ilmu Konservasi Gigi Program Studi Kedokteran Gigi Fakultas Kedokteran Universitas Sam Ratulangi
Email: dputong@gmail.com

\begin{abstract}
Dental caries is an oral health problem that many complaints by the people and needs serious attention because of its prevalence continues to increase. The treatment can be performed on one caries through restoration treatments. The purpose of this study is to describe caries and treatment needs restoration. This research is a descriptive study with Cross Sectional Study approach. The study was conducted in the Village Papusungan with the community sample aged 17 years and older with a sample of 106 people were obtained by using the formula Slovin. Checking the status of care needs restoration done with reference to the Treatment Need Index (TNI). The results showed that the highest care needs is the need for restoration of the surface of 60,96\%, followed by the restoration of the two surfaces of $23,91 \%$ and a low of three or more surface restoration $15,13 \%$.
\end{abstract}

Keywords : caries, restoration care need

Abstrak: Karies gigi merupakan masalah kesehatan gigi dan mulut yang banyak dikeluhkan oleh masyarakat dan perlu mendapat perhatian serius karena prevalensinya yang terus meningkat. Perawatan yang dapat dilakukan pada karies salah satunya melalui perawatan restorasi. Tujuan dari penelitian ini yaitu untuk mengetahui gambaran karies dan kebutuhan perawatan restorasi. Penelitian ini merupakan suatu penelitian deskriptif dengan pendekatan Study Cross Sectional. Penelitian dilakukan di Kelurahan Papusungan dengan sampel masyarakat yang berusia 17 tahun keatas dengan jumlah sampel 106 orang yang diperoleh dengan menggunakan rumus Slovin. Pemeriksaan status kebutuhan perawatan restorasi dilakukan dengan mengacu pada Treatment Need Index (TNI). Hasil penelitian menunjukkan bahwa kebutuhan perawatan tertinggi yakni kebutuhan akan restorasi satu permukaan $60,96 \%$, kemudian diikuti restorasi dua permukaan $23,91 \%$ dan yang terendah yaitu restorasi tiga atau lebih permukaan $15,13 \%$.

Kata kunci : Karies, kebutuhan perawatan restorasi 
Kesehatan gigi dan mulut merupakan suatu hal yang penting bagi kesehatan seseorang, namun masalah kesehatan gigi dan mulut salah satunya, yakni karies masih menduduki peringkat keenam penyakit yang paling banyak diderita masyarakat Indonesia. Berdasarkan data Kementerian Kesehatan tahun 2010 prevalensi karies mencapai $60-80 \%{ }^{1,2}$

Karies merupakan suatu penyakit pada jaringan keras gigi yang disebabkan oleh fermentasi jasad renik dalam suatu karbohidrat yang dapat diragikan. Pada stadium yang sangat dini proses ini masih dapat dihentikan namun pada stadium tertentu penyakit ini tidak dapat dihentikan. Jika karies tidak mendapat perawatan, maka lama kelamaan dapat mengakibatkan rasa sakit, terganggunya fungsi pengunyahan, fungsi bicara, estetika dan dapat menjadi infeksi fokal. ${ }^{3,4,5}$

Perawatan yang dapat dilakukan pada karies salah satunya melalui perawatan restorasi. Restorasi merupakan perawatan untuk mengembalikan struktur anatomi dan fungsi pada gigi, yang disebabkan fraktur, atrisi, abrasi, erosi dan karies. Berdasarkan Hasil Riset Kesehatan Dasar 2007 prevalensi Required Treatment Index (RTI) atau besarnya kerusakan karena karies yang belum mendapatkan perawatan yaitu sebesar 25,2\% dan prevalensi RTI tertinggi $35,3 \%$ terdapat di provinsi Sulawesi Utara. ${ }^{2,6}$
Kelurahan Papusungan merupakan salah satu kelurahan yang terdapat di kecamatan Lembeh kota Bitung propinsi Sulawesi Utara dengan jumlah penduduk 3327 jiwa. Hasil penelitian mahasiswa Praktek Belajar Lapangan (PBL) Program Studi Kedokteran Gigi Fakultas Kedokteran Universitas Sam Ratulangi tahun 2013 di kelurahan Papusungan menunjukkan rerata indeks DMFT pada perokok, anak-anak, pendidikan di atas Sekolah Menengah Pertama (SMP) dan pendidikan di bawah SMP yakni 6,08 yang di kategorikan sangat tinggi. ${ }^{7}$ Ketersediaan sumber daya manusia dalam bidang kesehatan gigi yang terdapat di kelurahan Papusungan tergolong masih kurang, dimana tenaga kesehatan gigi yang terdapat di daerah ini hanya perawat gigi sedangkan untuk tenaga dokter gigi belum ada. Kondisi ini mengakibatkan sulitnya masyarakat untuk mendapatkan pelayanan atau perawatan dalam bidang kesehatan gigi dan mulut. Mengingat besarnya dampak karies yang belum mendapatkan perawatan terhadap kesehatan secara keseluruhan dan belum tersedianya data tentang karies dan kebutuhan perawatan restorasi, maka peneliti tertarik untuk melakukan penelitian tentang karies dan kebutuhan perawatan restorasi di kelurahan Papusungan kecamatan Lembeh Selatan. 


\section{METODE PENELITIAN}

Penelitian ini merupakan penelitian deskriptif dengan menggunakan pendekatan cross sectional study. Penelitian ini dilakukan di kelurahan Papusungan, kecamatan Lembeh Selatan kota Bitung, provinsi Sulawesi Utara dan berlangsung pada bulan Agustus 2013 .

Populasi dalam penelitian ini yaitu masyarakat yang berusia 17 tahun keatas di kelurahan Papusungan berjumlah 2400 orang. Kriteria inklusi yaitu masyarakat yang bersedia dengan sukarela untuk mengikuti seluruh kegiatan penelitian dengan adanya persetujuan dan tanda tangan informed consent. Bersikap kooperatif selama pengambilan data. Kriteria eksklusi yaitu masyarakat yang telah kehilangan seluruh gigi dan yang menggunakan gigi tiruan penuh.

Metode pengambilan sampel yaitu purposive sampling. Data yang dikumpulkan pada tahap ini berupa data kondisi gigi subjek penelitian yang mengalami karies yang didasarkan pada banyaknya permukaan yang terkena. Data dicatat pada formulir pemeriksaan yang sudah disiapkan terlebih dahulu, untuk kemudian ditentukan kebutuhan perawatannya yang mengacu pada kebutuhan perawatan restorasi berdasarkan TNI.

\section{HASIL}

Pada penelitian ini karakteristik subjek penelitian dilihat berdasarkan usia, jenis kelamin dan tingkat pendidikan. Berikut ini distribusi frekuensi subjek penelitian berdasarkan kelompok usia (Tabel 1).

Tabel 1. Distribusi frekuensi subjek penelitian berdasarkan usia

\begin{tabular}{ccc}
\hline Usia & $\mathrm{n}$ & $\%$ \\
\hline 17-26 Tahun & 13 & 12,26 \\
27-36 Tahun & 24 & 22,64 \\
37-46 Tahun & 36 & 33,96 \\
47-56 Tahun & 19 & 17,92 \\
57-66 Tahun & 8 & 7,55 \\
67-78 Tahun & 6 & 5,66 \\
\hline Total & 106 & 100 \\
\hline
\end{tabular}

Data pada tabel 2 menunjukkan bahwa jumlah subjek penelitian yang berusia 17-26 tahun sebanyak 13 orang $(12,26 \%)$, 27-26 tahun sebanyak 24 orang $(22,64 \%)$, $37-46$ tahun sebanyak 36 orang $(33,96 \%)$, 47-56 tahun sebanyak 19 orang $(17,92 \%)$, 57-66 tahun sebanyak 8 orang $(7,55 \%)$, 67-78 tahun sebanyak 6 orang $(5,66 \%)$.

Tabel 2. Distribusi frekuensi subjek penelitian berdasarkan jenis kelamin

\begin{tabular}{ccc}
\hline Jenis Kelamin & $\mathrm{n}$ & $\%$ \\
\hline Laki-laki & 37 & 34,9 \\
Perempuan & 69 & 65,1 \\
\hline Total & 106 & 100 \\
\hline
\end{tabular}

Berdasarkan hasil yang diperoleh pada tabel 2 menunjukkan bahwa dari 106 jumlah subjek penelitian yang diteliti terdapat 37 orang $(34,9 \%)$ yang berjenis kelamin laki-laki dan 69 orang $(65,1 \%)$ yang berjenis kelamin perempuan. 
Tabel 3. Distribusi frekuensi subjek penelitian berdasarkan tingkat pendidikan

\begin{tabular}{ccc}
\hline Tingkat Pendidikan & $\mathrm{n}$ & $\%$ \\
\hline SD & 25 & 23,6 \\
SMP & 30 & 28,3 \\
SMA & 40 & 37,7 \\
Perguruan Tinggi (PT) & 11 & 10,4 \\
\hline Total & 106 & 100 \\
\hline
\end{tabular}

Pada tabel 3 dapat dilihat bahwa subjek penelitian terbanyak yaitu pada tingkat pendidikan SMA berjumlah 40 orang $(37,73 \%)$, SMP berjumlah 30 orang $(28,3 \%)$, SD berjumlah 25 orang $(23,59 \%)$ dan jumlah yang paling sedikit merupakan subjek penelitian dengan tingkat pendidikan PT yaitu berjumlah 11 orang $(10,28 \%)$.

Hasil penelitian menunjukkan tentang karies yang terkena pada banyaknya permukaan (Tabel 4).

Tabel 4. Distribusi frekuensi karies berdasarkan banyak permukaan yang terkena

\begin{tabular}{lcc}
\hline Karies berdasarkan banyak permukaan terkena & $\mathrm{n}$ & $\%$ \\
\hline Simple caries & 275 & 59,9 \\
Compound caries & 112 & 24,4 \\
Complex caries & 72 & 15,7 \\
\hline Total & 459 & 100 \\
\hline
\end{tabular}

Berdasarkan data yang ditampilkan pada tabel 5 diatas menunjukkan bahwa persentase simple caries yakni 275 gigi $(59,91 \%)$, compound caries yakni 112 gigi $(24,4 \%)$ dan complex caries yakni sebesar $15,69 \%$.
Hasil penelitian tentang kebutuhan perawatan restorasi pada gigi yang mengalami karies (Tabel 5).

Tabel 5. Distribusi frekuensi berdasarkan kebutuhan perawatan restorasi

\begin{tabular}{|c|c|c|}
\hline Kebutuhan Perawatan & $\mathrm{n}$ & $\%$ \\
\hline Membutuhkan & 459 & 16,2 \\
\hline Tidak Membutuhkan & 2374 & 83,8 \\
\hline Total & 2833 & 100 \\
\hline
\end{tabular}

Data yang ditampilkan pada tabel 5 menunjukkan bahwa dari 2833 gigi (100\%) yang diperiksa terdapat 459 gigi $(16,2 \%)$ yang membutuhkan perawatan dan 2374 gigi $(83,8 \%)$ yang tidak membutuhkan perawatan.

Hasil penelitian tentang kebutuhan perawatan restorasi yang didasarkan pada jenis perawatan pada permukaan yang terkena karies (Tabel 6).

Tabel 6. Distribusi frekuensi kebutuhan perawatan restorasi yang didasarkan pada jenis perawatan

\begin{tabular}{lcc}
\hline \multicolumn{1}{c}{ Jenis Perawatan } & $\mathrm{n}$ & $\%$ \\
\hline Restorasi satu permukaan & 275 & 59,9 \\
Restorasi dua permukaan & 112 & 24,4 \\
Restorasi tiga atau lebih permukaan & 72 & 15,7 \\
\hline Total & 459 & 100 \\
\hline
\end{tabular}

Tabel 6 diatas menunjukkan bahwa persentase kebutuhan perawatan restorasi tertinggi pada jenis perawatan restorasi satu permukaan sebesar 275 gigi $(59,91 \%)$, kemudian diikuti oleh restorasi dua permukaan sejumlah 112 gigi $(24,4 \%)$ dan 
yang terendah restorasi tiga atau lebih permukaan sejumlah 72 gigi $(15,69 \%)$.

Hasil penelitian tentang kebutuhan perawatan restorasi yang didasarkan pada seluruh elemen gigi yang mengalami karies gigi pada rahang atas (Tabel 7).

Tabel 7. Distribusi frekuensi kebutuhan perawatan restorasi berdasarkan elemen gigi yang terkena karies pada rahang atas

\begin{tabular}{ccccccc}
\hline \multirow{2}{*}{ Elemen Gigi } & \multicolumn{6}{c}{ Kebutuhan Perawatan } \\
\cline { 2 - 8 } & \multicolumn{3}{c}{1} & \multicolumn{4}{c}{2} & \multicolumn{3}{c}{3} \\
\hline $\mathrm{I} 1$ & 5 & 2,2 & 7 & 3,08 & 3 & 1,32 \\
$\mathrm{I} 2$ & 3 & 1,32 & 2 & 0,88 & 2 & 0,88 \\
$\mathrm{C}$ & 1 & 0,44 & 0 & 0 & 2 & 0,88 \\
$\mathrm{P} 1$ & 7 & 3,08 & 3 & 1,32 & 2 & 0,88 \\
$\mathrm{P} 2$ & 17 & 7,49 & 3 & 1,32 & 3 & 1,32 \\
$\mathrm{M} 1$ & 53 & 23,35 & 20 & 8,81 & 10 & 4,4 \\
$\mathrm{M} 2$ & 64 & 28,19 & 16 & 7,05 & 4 & 1,76 \\
\hline Total & 150 & 66,08 & 51 & 22,47 & 26 & 11,45 \\
\hline Ket: 1= & Restorasi & satu & permukaan, & $2=$ \\
Restorasi dua permukaan, & $3=$ \\
atau lebih permukaan & \multicolumn{7}{c}{ Restorasi tiga }
\end{tabular}

Hasil yang didapat pada tabel 7 menunjukkan bahwa kebutuhan perawatan restorasi jika diurutkan berdasarkan elemen gigi pada rahang atas, maka terlihat persentase tertinggi pada gigi molar kedua sejumlah $64(28,19 \%)$ yang membutuhkan restorasi satu permukaan, kemudian molar pertama sejumlah 53 (23,35\%), premolar kedua sejumlah 17 (7,49\%), premolar pertama sejumlah 7 $(3,08 \%)$, insisivus pertama sejumlah 5 $(2,2 \%)$, insisivus kedua sejumlah 3 $(1,32 \%)$, dan yang terendah yakni pada kaninus sejumlah $1(0,44 \%)$.
Hasil penelitian tentang kebutuhan perawatan restorasi yang didasarkan pada seluruh elemen gigi yang mengalami karies gigi pada rahang bawah (Tabel 8).

Tabel 8. Distribusi frekuensi kebutuhan perawatan restorasi berdasarkan elemen gigi yang terkena karies pada rahang bawah

\begin{tabular}{ccccccc}
\hline & \multicolumn{6}{c}{ Kebutuhan Perawatan } \\
\cline { 2 - 7 } Elemen Gigi & \multicolumn{5}{c}{1} & \multicolumn{3}{c}{3} \\
& $\mathrm{n}$ & $\%$ & $\mathrm{n}$ & $\%$ & $\mathrm{n}$ & $\%$ \\
\hline $\mathrm{I} 1$ & 2 & 0,86 & 0 & 0 & 0 & 0 \\
$\mathrm{I} 2$ & 2 & 0,86 & 0 & 0 & 0 & 0 \\
$\mathrm{C}$ & 2 & 0,86 & 1 & 0,43 & 1 & 0,43 \\
$\mathrm{P} 1$ & 5 & 2,15 & 2 & 0,86 & 4 & 1,72 \\
$\mathrm{P} 2$ & 16 & 6,9 & 7 & 3,02 & 11 & 4,74 \\
$\mathrm{M} 1$ & 45 & 19,39 & 30 & 12,93 & 17 & 7,33 \\
$\mathrm{M} 2$ & 54 & 23,27 & 21 & 9,05 & 12 & 5,17 \\
\hline Total & 126 & 54,3 & 61 & 26,3 & 45 & 19,4 \\
\hline Ket: 1= Restorasi satu & permukaan, & $2=$ \\
Restorasi dua permukaan, $3=$ & Restorasi tiga \\
atau lebih permukaan
\end{tabular}

Berdasarkan hasil yang ditampilkan pada tabel 8 menunjukkan bahwa kebutuhan perawatan restorasi jika diurutkan berdasarkan elemen gigi pada rahang bawah, maka persentase tertinggi yakni pada gigi molar kedua sejumlah 54 gigi $(23,27 \%)$ yang membutuhkan perawatan restorasi satu permukaan, molar pertama sejumlah 45 gigi $(19,39 \%)$, premolar kedua sejumlah 16 gigi $(6,9)$, premolar pertama sejumlah 5 gigi $(2,15 \%)$, dan yang terendah yakni pada gigi kaninus, insisivus pertama dan insisivus kedua dengan jumlah masing-masing 2 gigi $(0,87 \%)$ yang membutuhkan perawatan restorasi satu permukaan. 
Hasil penelitian tentang kebutuhan perawatan restorasi yang dilihat berdasarkan regio rahang (Tabel 9).

Tabel 9. Distribusi frekuensi kebutuhan perawatan restorasi berdasarkan regio rahang

\begin{tabular}{|c|c|c|c|c|}
\hline \multirow{3}{*}{ Jenis Perawatan } & \multicolumn{4}{|c|}{ Regio Rahang } \\
\hline & \multicolumn{2}{|c|}{ Rahang Atas } & \multicolumn{2}{|c|}{ Rahang Bawah } \\
\hline & $\mathrm{n}$ & $\%$ & $\mathrm{n}$ & $\%$ \\
\hline$\overline{\text { Restoarsi satu permukaan }}$ & 149 & 65,64 & 126 & 54,31 \\
\hline Restorasi dua permukaan & 51 & 22,47 & 61 & 26,29 \\
\hline Restorasi tiga atau lebih permukaan & 27 & 11,89 & 45 & 19,4 \\
\hline Total & 227 & 100 & 232 & 100 \\
\hline
\end{tabular}

Berdasarkan data yang ditunjukkan pada tabel 9 dapat dilihat bahwa persentase kebutuhan perawatan restorasi tertinggi yaitu pada regio rahang atas dengan jenis perawatan restorasi satu permukaan sejumlah 149 gigi $(65,64 \%)$, kemudian restorasi dua permukaan sejumlah 51 gigi $(22,47 \%)$ dan yang terendah jenis perawatan restorasi tiga atau lebih permukaan, yakni sebanyak 27 gigi $(11,89 \%)$. Untuk regio rahang bawah tidak jauh berbeda dengan rahang atas dimana persentase tertinggi yakni jenis perawatan restorasi satu permukaan sejumlah 126 gigi $(54,31 \%)$, kemudian diikuti perawatan restorasi dua permukaan sejumlah 61 gigi $(26,29 \%)$ dan yang terendah yakni restorasi tiga atau lebih permukaan yaitu sejumlah 45 gigi $(19,4 \%)$.

\section{Pembahasan}

Hasil penelitian yang dilakukan pada masyarakat di kelurahan Papusungan kecamatan Lembeh Selatan menunjukkan bahwa kebutuhan perawatan restorasi hanya sejumlah $16,2 \%$. Jika melihat angka ini bisa menimbulkan persepsi yang keliru. Orang dapat berpendapat bahwa kondisi kesehatan gigi dan mulut responden cukup baik karena jumlah gigi yang rusak dan membutuhkan perawatan hanya sedikit. Namun keadaan ini belum menggambarkan kondisi yang sebenarnya. Penulis menemukan ada gigi yang telah mengalami karies akan tetapi gigi tersebut tidak bisa dilakukan perawatan restorasi dan diindikasikan untuk dilakukan ekstraksi, serta didapati banyak yang mengalami kehilangan gigi. Kondisi kesehatan gigi dan mulut responden tergambar dari hasil penelitian tentang karies berdasarkan banyaknya permukaan yang terkena yakni simple caries 275 (59,91\%), compound caries 112 (24,4\%), complex caries 72 (15,69\%). Kondisi ini juga tergambar dari indeks DMF-T yang diteliti oleh mahasiswa Praktek Belajar Lapangan (PBL) Program Studi Kedokteran Gigi Fakultas Kedokteran Universitas Sam Ratulangi tahun 2013 pada masyarakat di kelurahan Papusungan kecamatan Lembeh Selatan yakni sebesar 6,08. Penelitian ini jauh berbeda dengan penelitian yang dilakukan oleh Veneet dkk 
yang menunjukkan persentase kebutuhan perawatan restorasi sebanyak $86,78 \%$. Perbedaan ini dikarenakan hampir $80 \%$ masyarakat India yang tinggal di daerah pedesaan seperti Udaipur tidak memiliki akses untuk mendapatkan perawatan kesehatan gigi dan mulut. ${ }^{7,8,9}$

Distribusi hasil penelitian kebutuhan perawatan restorasi berdasarkan jenis perawatan menunjukkan bahwa yang tertinggi yaitu kebutuhan perawatan restorasi satu permukaan sejumlah $59,91 \%$, kemudian diikuti kebutuhan perawatan restorasi dua permukaan sejumlah $24,4 \%$ dan yang terendah yakni kebutuhan perawatan restorasi tiga atau lebih permukaan sejumlah 15,69\%. Hasil penelitian ini perkuat dengan penelitian yang dilakukan oleh Fabio dkk, Harpreet dkk dan Sudhanshu dimana angka kebutuhan perawatan yang tertinggi yakni kebutuhan restorasi satu permukaan. ${ }^{10,11,12}$ Keadaan ini terjadi karena masyarakat masih belum memahami dan menyadari akan pentingnya menjaga kesehatan gigi dan mulut sehingga keinginan untuk melakukan perawatan restorasi masih sangat rendah, ditambah lagi belum tersedianya sarana dan prasarana untuk melakukan perawatan restorasi serta kurangnya tindakan promotif dan preventif yang dilakukan oleh perawat gigi di kelurahan Papusungan kecamatan Lembeh Selatan.
Berdasarkan hasil penelitian kebutuhan perawatan restorasi pada subjek penelitian berdasarkan elemen gigi menunjukkan bahwa persentase tertinggi terdapat pada gigi molar kedua sejumlah 174 gigi $(38,07 \%)$, gigi molar pertama sejumlah 171 gigi $(37,42 \%)$, gigi premolar kedua sejumlah 56 gigi $(12,25 \%)$, gigi premolar pertama sejumlah 23 gigi $(5,03 \%)$, gigi insisivus pertama sejumlah 17 gigi $(3,72 \%)$ dan gigi insisivus kedua sejumlah 9 gigi $(1,97 \%)$ dan yang terendah terdapat pada gigi kaninus yaitu 7 gigi $(1,53 \%)$. Hal ini tidak jauh berbeda dengan penelitian yang dilakukan oleh Mon Mon Tin dkk yang dilakukan di Malaysia dimana angka kebutuhan perawatan restorasi berdasarkan elemen gigi yang tertinggi yaitu terdapat pada gigi molar pertama. $^{13}$

Hal diatas dikarenakan gigi molar paling banyak mengalami karies dan morfologi gigi molar yang memiliki pit dan fisur. Fisur terbentuk saat perkembangan alur, dan tidak sepenuhnya menyatu sehingga membuat suatu turunan atau depresio yang khas pada struktur permukaan email. Pit dan fisur juga merupakan bagian yang paling mudah terkena karies. Sisa-sisa makanan yang masuk pada daerah tersebut sulit untuk dibersihkan sehingga mikroba dapat beraktivitas dan menghasilkan asam yang dapat menyebabkan terjadinya karies. 
Selain itu gigi molar pertama juga merupakan gigi yang paling pertama erupsi di dalam rongga mulut, sehingga gigi tersebut lebih sering dan lebih lama berkontak dengan makanan. Berbeda dengan letak gigi kaninus yang berada pada bagian anterior yang lebih mudah dijangkau oleh sikat gigi untuk dilakukan pembersihan. Selain itu pada gigi insisivus lebih jarang terkena karies karena terdapat muara saliva yang bekerja secara langsung untuk membersihkan bagian gigi insisivus atau yang disebut dengan self cleansing. Dilihat dari kondisi gigi yang mengalami karies dan membutuhkan perawatan restorasi lebih banyak terdapat pada gigi bagian posterior. Keadaan ini menunjukkan pemahaman masyarakat tentang cara memelihara dan merawat kesehatan gigi dan mulut masih kurang sehingga masyarakat lebih cenderung membersihkan gigi dibagian anterior dibandingkan gigi dibagian posterior. Masyarakat juga memiliki pemahaman bahwa lebih baik mempertahankan gigi anterior dibandingkan gigi posterior karena masyarakat menganggap gigi anterior lebih diperlukan untuk kebutuhan estetik.

Hasil penelitian pada kebutuhan perawatan restorasi berdasarkan regio rahang menunjukkan bahwa kebutuhan perawatan restorasi paling banyak terjadi pada regio rahang bawah sejumlah 232 gigi $(50,54 \%)$ dibandingkan pada rahang atas sejumlah 227 gigi $(49,45 \%)$. Hal ini sama dengan penelitian yang dilakukan oleh Mon Mon Tin dkk yang dilakukan di Malaysia dimana angka kebutuhan perawatan restorasi berdasarkan regio rahang yang tertinggi yakni pada regio rahang bawah dan yang terendah yakni pada regio rahang atas. ${ }^{14}$ Keadaan ini menunjukkan bahwa karies lebih banyak menyerang gigi rahang bawah. Hal ini terjadi karena hampir semua gigi geligi pada rahang bawah lebih dahulu erupsi dibandingkan pada rahang atas sehingga risiko untuk terjadi karies lebih tinggi. Jika dilihat dari gaya gravitasi aliran air di dalam mulut, maka aliran air lebih mudah mengalir ke bagian bawah dan sisa-sisa makanan akan lebih banyak mengendap di bagian rahang bawah, sehingga apabila tidak dibersihkan dalam waktu yang lama akan meningkatkan risiko terjadinya karies.

\section{SIMPULAN DAN SARAN}

Gambaran karies berdasarkan banyaknya permukaan yang terkena sebagai berikut: Simple caries 275 gigi $(59,91 \%)$, compound caries 112 gigi $(24,4 \%)$ dan complex caries 72 gigi $(15,69 \%)$. Kebutuhan perawatan restorasi paling banyak yaitu kebutuhan restorasi satu permukaan yakni $59,91 \%$, restorasi dua permukaan yakni 24,4\% dan paling sedikit restorasi tiga atau lebih permukaan 
yakni 15,69\%. Masyarakat diharapkan lebih memerhatikan kesehatan gigi dan mulut khususnya dalam menanggulangi masalah karies dengan melakukan perawatan yang sesuai dengan kebutuhan perawatan restorasi. Bagi institusi kesehatan diharapkan dapat meningkatkan program pelayanan kesehatan gigi dan mulut yang sesuai dengan keadaan karies berdasarkan permukaan terkena dan kebutuhan perawatan yang diperlukan masyarakat.

\section{DAFTAR PUSTAKA}

1. Tempo Interactive. 60 Pesen Penduduk Indonesia Pernah Sakit Gigi. [Online] 2008 [cited 2013 April 14]; Available from: URL:http://www.tempointeractive.co $\mathrm{m} / \mathrm{hg} /$ nasional/

2. Badan Peneliti dan Pengembangan Kesehatan RI. Laporan hasil riset kesehatan dasar nasional tahun 2007. Jakarta: Departemen Kesehatan RI; 2008. h. 129-146.

3. Kidd E.A.M, Bechal.S. Dasar-dasar karies (penyakit dan penanggulangannya). Diterjemahkan oleh Narlan Sumawinata dan Safrida Faruk. Jakarta: EGC. 1991. h. 1

4. Meghashyam B, Nagesh L, Ankola A. Dental caries and treatment needs of children of fisher folk communities, residing in the coastal areas of Karnataka region, south India. West India Med J; 2007. p. 56-96.

5. Bruvo M, Ekstrand K, Arvin E, Spliid H, Moe D, Kirkeby S, Bardow A, Optimal drinking water composition for caries control in population. J Dent Res [serial online] 2008 [cited: April 2013]; 87 (4): 340-343. Available from:URL:http://jdr.sagepub.com/cont ent/87/4/340
6. Baum L, Lund M.R, Phillips R.W. Buku ajar ilmu konservasi gigi (textbook of operative dentistry). Diterjemahkan oleh Rasinta Tarigan. Jakarta: EGC. 1997. h. 36, 182

7. Kelompok Praktek Belajar Lapangan Mahasiswa Kedokteran Gigi Universitas Sam Ratulangi. Laporan Kohor Kesehatan Gigi dan Mulut Kelurahan Papusungan; 2013.

8. Dhar V, Bhatnagar M. Dental caries and treatment needs of children (610years) in rural Udaipur, Rajastan. Indian J Dent Res. 2009; 20: h. 256 60.

9. Dhar V, Jain A, Van Dyke TE, Kohli A. Prevalence of Dental caries and treatment needs in the school going children of rural areas in Udaipur Distric. J Indian Soc Pedo Prev Dent 2007;25:119 - 121

10. Grewal h, Kumar A, Verna M. Prevalensi of dental caries and treatment needs amongst the school children of three educational zones of urban Delhi, India. Indian J Dent Res. 2011;22(4): p. $517-9$.

11. Sampaio FC, Freitas CHSM, Cabral MBF, Marchado ATAB. Dental caries and treatment needs among indigenous of the potiguara Indian reservation in Brazil. Rev panam salud publica. 2010;27(4);p. $246-251$.

12. Bhat, M. Oral health status and treatment needs of a rural Indian fishing community. West Indian med. j. vol.57 no. 4 Mona Sept. 2008.

13. Tin M, Naing L, Mani S. Dental caries experience and treatment needs in the mixed dentition in North East Malaysia. Arch Orofac Sci. 2011;6(2);p. 1 - 8 .

14. Rao V, Suresh, Ahmed Z. Dentition Status and Treatment Needs of 5 and 12 Year Old School Children in Urban and Rural Areas of Guntur, India. J Oral Health Comm Dent 2012;6(3);p. $126-130$. 